\title{
A Comparison of the Tactical Game Approach and the Direct Teaching Models in the Teaching of Handball: Cognitive - Psychomotor Field and Game Performance
}

\author{
Ferudun Dorak ${ }^{1}$, Lale Yildiz ${ }^{1, *}$, A. Meliha Canpolat ${ }^{1}$, Yasin Yüzbaşığllu ${ }^{1} \&$ Nilgün Vurgun ${ }^{2}$ \\ ${ }^{1}$ Ege University, Turkey \\ ${ }^{2}$ Manisa Celal Bayar University, Turkey \\ *Correspondence: Ege University, Turkey. E-mail: laleyildiz84@gmail.com
}

Received: April 24, 2018

Accepted: May 29, $2018 \quad$ Online Published: June 13, 2018

doi:10.5430/wje.v8n3p76

URL: https://doi.org/10.5430/wje.v8n3p76

\begin{abstract}
It was aimed in the study to compare the Tactical Game Approach and the Direct Learning Models in Handball training, to study the effects in detail on development in the cognitive field, psychomotor field and game performance of these models. A total of 43 students who were attending at the Department of Physical Education and Sports Teaching, participated voluntarily in this study. Since the participants were attending two different classes, one of the classes was determined randomly as the "Tactical Game Group" $(n=25)$ and the other class as the "Direct Learning Group" $(\mathrm{n}=18)$. In the study, a 25-question survey form composed by the experts, was used for measuring the knowledge levels. A Handball test course was used for determining performances of the psychomotor developments of the groups. The 16-item form that contained the offensive and defensive criteria, by taking as the basis the (GPAI), was used at the stage of game performance assessment. The qualitative data were obtained with the individual interview technique realized with the Standardized Open-ended Interview Form. Analysis methods were used for data analyses. In the analysis of the qualitative date, the depiction and analysis stages were followed. Study findings stated that both of the learning methods provided development, both in the psychomotor and in the cognitive field. However, in the game performance field, it was determined that the Tactical Game Approach was more effective compared to the Direct Learning Model.
\end{abstract}

Keywords: physical education, physical performance, qualitative research, teaching

\section{Introduction}

An effective teaching should provide students with an environment for understanding the information, for integration in the mind and for being able to perceive and implement new concepts, because even if learning is a product that is realized by students themselves, it is also shaped according to the teaching methods and techniques used by the teacher. It is emphasized in many studies that the different principles and strategies used in the implementation of these methods and techniques are important factors in being able to obtain a successful result (Lloyd, 2012; Stran \& Curtner-Smith, 2009; Stolz \& Pill, 2014; Tozer \& Horsley, 2006). Especially, it is known that the different principles and strategies used in physical education courses are used in many activities organized for effective learning and teaching (SHAPE America, 2015). In the process up until the present-day, it is an indisputable fact that the "Direct Teaching Model" is one of the teaching approaches used the most in physical education (Curtner-Smith et al, 2001; Metzler, 2005; Pritchard et al., 2008). Briefly, the Direct Teaching Model can be defined as a technique in which information is delivered directly to students and that is structured in a clear manner according to the targets of the course (Zembat, 2007). In this teaching technique, it is dependent on the inner-class authoritarian behaviors of the teacher to provide for the student to learn and to establish a bridge between the teaching aims of the course with the experiences of the student (İnce \& Hünük, 2010; Gıbbs \& Coffey 2004). The process of implementation of a teaching technique in a class environment can be composed in very different structures according to different subject fields and different class levels (Aelterman et al., 2013). In general, the direct teaching model implemented in physical education courses is structured in the manner of showing examples with the control of the teacher, step-by-step advancement, using visual elements and presenting feedback (Smith et al., 2015). While a limited 
opportunity is given within the class for students to make decisions, most of the time, the responsibility is given only to follow the instructions of the teacher (Roberts \& Fairclough, 2011). On this point, the communication is one-sided from the teacher to the student (Metzler, 2005). Besides this, there are many different teaching methods that are suitable to the characteristics of the class for providing for the students to think, make decisions and participate actively (Bowering et al., 2007). Within these methods, one of the teaching models that provides for abundant learning experiences is the Tactical Game Approach (Dyson et al., 2004; McNeill \& Fry, 2010; Mitchell et al., 2003). In this approach, it is also aimed for the students to acquire different skills, such as game skills by being trained as developed students, to solve problems within cooperation and to ask questions (Griffin \& Butler, 2005). Among the necessities of this approach are the freer structuring of experiences, the students making more decisions and taking responsibility in the learning process and to also provide development for them in the behavioral and affective fields, not only in the cognitive field (Oslin et al., 1998). In the physical education courses structured with the tactical game approach, an area of freedom is created for the students to discover through games their own learning strategies, new ideas and awarenesses (Memmert \& Harvey, 2008). The student-centered games realized in such a field have been the subject of many studies on the effects on performance (Jenkinson \& Benson, 2009), because games are one of the most important training tools of our era. Especially, it is thought that the tactical game approach could be an effective method in the learning of team sports where the tactical solutions and period of making decisions in the field are rather rapid and of reaching the target aimed in offensive and defensive games (Chatzipanteli et al., 2016). One of the inside sports where the approach could be implemented is the handball branch of sports where offensive and defensive tactics are used very frequently.

In the process of assessing the learning and performance in this branch, how should the students be structured where the teacher is the guide? The question is frequently asked whether the teaching method that provides for the students to find their own meanings to the questions or the teaching method where the teacher is the role model and the students learn new skills with sequential training would be more effective. Furthermore, usually the studies in this field use unidirectional quantitative research designs and it is impossible to examine the findings in greater depth. Consequently, it was deemed valuable to use both the qualitative and the quantitative methods together in the research process. In this context, it was aimed in the study to compare the Tactical Game Approach and the Direct Learning Models in handball training, to study the effects in detail on development in the cognitive field, psychomotor field and game performance of these models and to contribute to educating teachers who create differences in teaching.

\section{Method}

\subsection{Model of the Study}

In the design of the study planned, more than one data collection method was used and place was also given to qualitative measurements with the objective of providing for the reliability of the study (Creswell, 2003). Handball training was implemented with two different teaching methods (Direct Teaching Model and Tactical Game Approach Model) for 3 hours/ week for a period of 12 weeks and a total of 36 hours of classes.

According to this, the design of the study was planned as given in Table 1 .

Table 1. Design of the Study

\begin{tabular}{cccc}
\hline Group & Measurement 1 & Implementation* $^{*}$ & Measurement 2 \\
\hline Tactical Game Approach & 1.HCA & -12 weeks handball training & 1.CFT \\
& $2 . \mathrm{CFT}$ & -36 hours movie camera taking & 3.PFT \\
& $3 . \mathrm{PFT}$ & - Weekly assessments of experts & $4 . \mathrm{QS}$ \\
Direct Teaching Model & $4 . \mathrm{GPA}$ & & \\
& $1 . H C A$ & -12 weeks handball training & 1.CFT \\
& $2 . C F T$ & -36 hours movie camera taking & $3 . P F T$ \\
& $3 . P F T$ & - Weekly assessments of experts & $4 . Q S$
\end{tabular}

*Handball course activities structured suitably to the teaching models (HCA)

SIF: Student Information Form, CFT: Cognitive Field Test, PFT: Psychomotor Field Test, GPA: Game Performance Assessment, QS: Qualitative Study 


\subsection{Participants}

A total of 43 students who did not have an athletic past in the handball branch of sports and who were attending the second year at the Department of Physical Education and Sports Teaching of local University, School of Physical Education and Sports, participated voluntarily in this study. Since the participants were attending two different classes, one of the classes was determined randomly as the "Tactical Game Group" ( $\mathrm{n}=25)$ and the other class as the "Direct Learning Group" ( $\mathrm{n}=18)$.

\subsection{Data Collection Tools}

\subsubsection{Cognitive Field Data Collection Tools}

In the study, a 25-question survey form constituted with the mixed test technique was composed by the three expert teaching staff who were also the co-authors of the study 1) 5th level trainer / club and national teams trainer and a former handball player, 2) 4th level trainer / club and national teams trainer and a former handball player and 3) 1st level trainer / active national competitive handball player at present]. These experts scored the knowledge levels of the participants for the handball game.

\subsubsection{Psychomotor Field Data Collection Tools}

A handball test course was used and prepared by the experts for determining the pre-test and final test performances of the psychomotor developments of the groups in the study (Figure 1). The test course performances of the participants were determined with the assessment of the handball skills expected to be realized at every station within the course. This assessment was made with a 40 -item assessment form prepared by the experts. This assessment form was filled in the manner of "related skill was observed" or "related skill was not observed" according to the situation of realizing or not realizing the skills at the stations. From the psychomotor field skills, the measurements of dribbling the ball, basic throwing of the ball, throwing by dropping, deception, throwing by jumping, holding the ball and defense were taken as the basis.

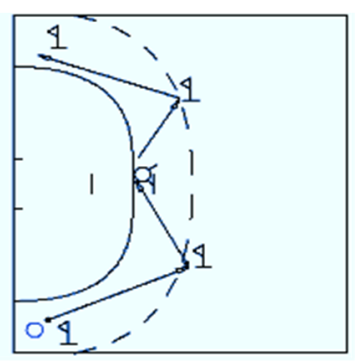

$-1-$

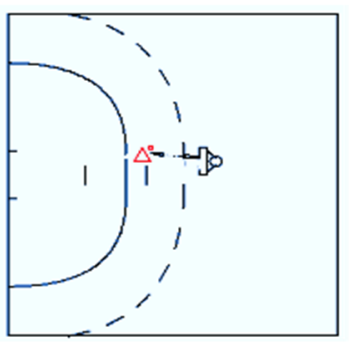

$-4-$

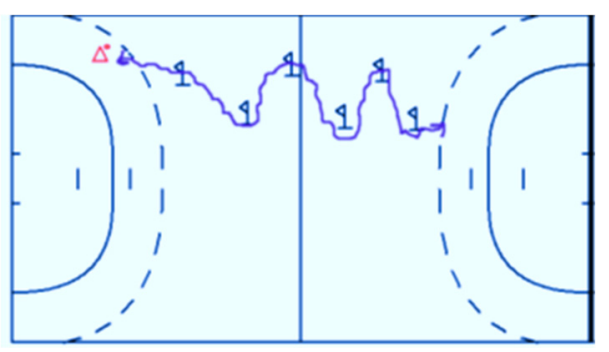

$-2-$

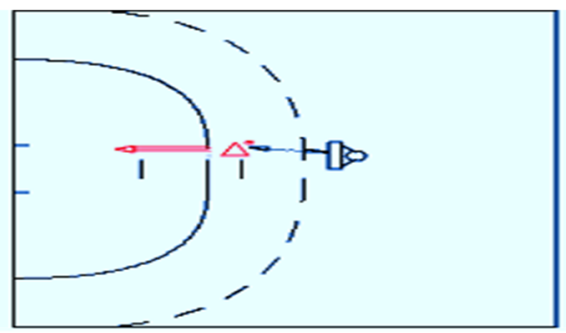

$-5-$

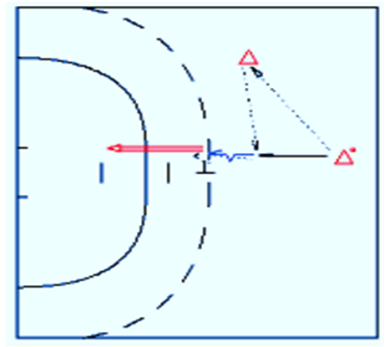

$-3-$

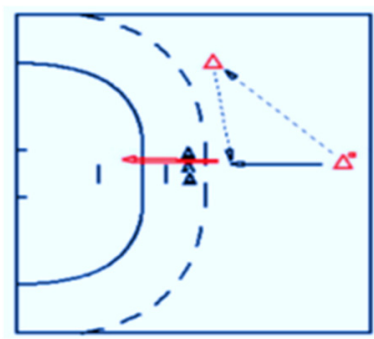

$-6-$

Figure 1. Psychomotor Field Test Course for the Handball Branch of Sports

1. Defense (Coming to the Front - Retreat - Block - Coming to the Front - Retreat)

2. Dribbling (6 throws / 1 go-come)

3. Deception (for the right hand; deception to the left - passing from the right and throwing by jumping)

4. Holding and throwing the Ball (It is thrown 6 times to the reflector and held)

5. Throwing by Dropping (Turn and throw the ball coming from the reflector -2 times to the upper corners)

6. Throwing to the Target from 8 meters (a. Basic Throw / 2 lower -2 upper corners, b. Throwing by jumping / 2 lower -2 upper corners) 


\subsubsection{Data Collection Tools for Evaluating Game Performance}

The 16-item form that contained the offensive and defensive criteria, which was prepared by experts by taking as the basis the Game Performance Assessment Instrument (GPAI) developed by Griffin, Mitchell and Oslin (1997), was used at the stage of game performance assessment.

The participator's performances that were recorded with a video camera (Sony-HD) were later studied off-line in detail by the experts. The game performance assessment scale was given points in the form of "suitable" and "unsuitable". In the subsequent process, by calculating separately the points for offense and defense for the decision-making index, skills performance index and support index, the offense game performances and defense game performances values were obtained. Finally, by taking the average of these values obtained, the general game performance index was calculated:

$$
\begin{gathered}
\text { Suitable Behavior }=\frac{\text { Expert Suitable Decision Totals }}{3} \\
\text { Unsuitable Behavior }=\frac{\text { Expert Unsuitable Decision Totals }}{3} \\
\text { Game Performance Index }=\frac{\text { Suitable Behavior }}{\text { Suitable Behavior }+ \text { Unsuitable Behavior }}
\end{gathered}
$$

\subsubsection{Qualitative Data Collection Tools}

The qualitative data were obtained with the individual interview technique realized with the student interview form. The interviews were recorded on camera and subsequently, by putting the interviews into writing, analyses were made for depth and abundance of data (Berg, 2004).

\subsubsection{Standardized Open-ended Interview Form}

The Interview Form was prepared at the end of the 12-week handball training of the participants with the objective of describing the dimensions of the cognitive, psychomotor and game performance dimensions for this branch and how the participants assessed themselves and their levels of development. At this stage, the questions that were prepared carefully by being put in a specific order were asked to each of the participants in the same manner and order. Furthermore, in case the individual did not understand the question, the necessary clues were also prepared. There were a total of 12 questions on the standardized open-ended interview form, with 3 close-ended and 9 open-ended questions in response to the participants' assessments of their own developments and observations prior to and after the 12-week handball game training.

Sample Questions:

"How much did you know about the handball branch of sports prior to training? When you assess yourself on a total of 10 , how many points would you give to yourself?"

"-At the end of the 12-week training, what sort of a change/development did you observe in the cognitive field of the handball branch of sports?"

\subsection{Analysis of the Data}

\subsubsection{Analysis of the Quantitative Data}

The analysis of the quantitative data obtained in the study was made by using the IBM Statistical Package for the Social Sciences (SPSS) 18.0 package program. The Wilcoxon Signed-Rank Test or the Paired Student's t-Test were used in the intra-group assessments, whereas, the Mann Whitney U Test or the Unpaired Student's t-Test were used in the inter-group assessments connected to whether or not the data had a normal distribution. Whereas, definitive statistics were used in the assessment of game performance. The level of significance in all of the statistical analyses was accepted to be $\mathrm{p}<.05$.

\subsubsection{Analysis of the Qualitative Data}

In general, in the analysis of the qualitative date, the depiction and analysis stages were followed (Yildirım and Şimşek, 2008). First of all, for analyzing the interviews, the talks recorded during the interview were put into writing. The descriptive analysis method was used with the objective of presenting the findings obtained to the reader in a 
summarized form (Gürbüz \& Şahin, 2014). The researchers brought the findings together by determining what were the concepts related to the theoretical framework and objective. The SPSS package program was used in the analysis of the coded data.

\section{Findings}

Table 2. Assessment of the Success Index for the Psychomotor Field Skills of the Direct Learning Model Group

\begin{tabular}{lcccc}
\hline & $\begin{array}{c}\text { Pre-test } \\
(\bar{X} \pm \mathrm{SD})\end{array}$ & $\begin{array}{c}\text { Post-test } \\
(\bar{X} \pm \mathrm{SD})\end{array}$ & $\Delta \%$ & $\mathbf{t}$ \\
\hline Basic Throw & $0.18 \pm 0.24$ & $0.74 \pm 0.17$ & 311 & $-8.97^{* *}$ \\
Throwing by jumping & $0.31 \pm 0.29$ & $0.89 \pm 0.12$ & 187 & $-8.22^{* *}$ \\
Throwing by Dropping & $0.21 \pm 0.29$ & $0.73 \pm 0.25$ & 247 & $-5.53^{* *}$ \\
Holding the ball & $0.56 \pm 0.25$ & $0.86 \pm 0.13$ & 53.5 & $-5.30^{* *}$ \\
Throwing the ball & $0.56 \pm 0.28$ & $0.93 \pm 0.12$ & 66.0 & $-6.06^{* *}$ \\
Deception & $0.46 \pm 0.34$ & $0.92 \pm 0.14$ & 100 & $-5.89^{* *}$ \\
Defence & $0.20 \pm 0.19$ & $0.76 \pm 0.10$ & 280 & $-12.0^{* *}$ \\
\hline
\end{tabular}

$=18), * * p<.001 ; \Delta \%=$ Percentage change in means; $S D=$ Standard Deviation

As it can be observed in Table 2, when the first and final measurements for the success indices were compared for the psychomotor field tests for the direct learning model, it was found that there was a statistically significant increase in all of the skills $(\mathrm{p}<.001)$.

Table 3. Assessment of the Success Index for the Psychomotor Field Skills of the Tactical Game Approach Group

\begin{tabular}{lcccc}
\hline & $\begin{array}{c}\text { Performance Index } \\
\text { Pre-test } \\
(\bar{X} \pm \text { SD })\end{array}$ & $\begin{array}{c}\text { Performance Index } \\
\text { Post- test } \\
(\bar{X} \pm \text { SD })\end{array}$ & $\Delta \%$ & t \\
\hline Basic Throw & $0.37 \pm 0.28$ & $0.82 \pm 0.14$ & 122 & $-8.84^{* *}$ \\
Throwing by jumping & $0.34 \pm 0.29$ & $0.93 \pm 0.13$ & 174 & $-9.10^{* *}$ \\
Throwing by Dropping & $0.25 \pm 0.25$ & $0.88 \pm 0.16$ & 252 & $-13.0^{* *}$ \\
Holding the ball & $0.58 \pm 0.32$ & $0.82 \pm 0.12$ & 41.4 & $-3.73^{* *}$ \\
Throwing the ball & $0.65 \pm 0.30$ & $0.98 \pm 0.06$ & 50.8 & $-5.34^{* *}$ \\
Deception & $0.42 \pm 0.32$ & $0.94 \pm 0.11$ & 124 & $-8.22^{* *}$ \\
Defence & $0.50 \pm 0.26$ & $0.81 \pm 0.14$ & 62.0 & $-6.09^{* *}$ \\
\hline
\end{tabular}

$(n=25),{ }^{*} p<.001 ; \Delta \%=$ Percentage change in means; $S D=$ Standard Deviation

When the values on Table 3 were examined, when the first and final measurements for the success indices were compared for the psychomotor field tests for the tactical game approach group, it was found that there was a statistically significant increase in all of the skills $(\mathrm{p}<.001)$.

Table 4. Intra-Group Assessment of the Status of Success for the Psychomotor Field

\begin{tabular}{ccccc}
\hline & \multicolumn{5}{c}{ General Performance Position } \\
\hline Psychomotor Field & n & $\begin{array}{c}\text { Pre-test } \\
\left(X^{-} \pm \mathrm{SD}\right)\end{array}$ & $\begin{array}{c}\text { Post-test } \\
(\bar{X} \pm \mathrm{SD})\end{array}$ & $\mathbf{t}$ \\
\hline Direct Teaching Model & 18 & $0.35 \pm 0.16$ & $0.83 \pm 0.08$ & $14.0^{* *}$ \\
Tactical Game Approach & 25 & $0.45 \pm 0.19$ & $0.88 \pm 0.07$ & $12.6^{* *}$ \\
\hline$* p<.001$ & & &
\end{tabular}


The general status of success for both groups was found by taking the average of the indices for the psychomotor field skills. The intra-group change of the status of general success for both groups has been shown in Table 4. When both groups were assessed within themselves, it was determined that there was a statistically significant increase ( $p$ $<.001)$.

Table 5. Inter-Group Assessment of the General Success Levels of Increase for the Psychomotor Field

\begin{tabular}{cccc}
\hline & & $\begin{array}{c}\text { General Performance } \\
\text { Increase Level (\%) }\end{array}$ & \\
\hline Group & $\mathbf{n}$ & $(\bar{X} \pm$ SD) & t \\
\hline Direct Teaching Model & 18 & $197 \pm 166$ & 1.14 \\
Tactical Game Approach & 25 & $146 \pm 126$ & 1.6 \\
\hline
\end{tabular}

The inter-group percentage development differences were not statistically significant $(\mathrm{p}>.05$; Table 5$)$.

Table 6. Intra-Group Assessment of the Test Results for the Cognitive Field

\begin{tabular}{ccccc}
\hline & \multicolumn{5}{c}{ Performance Increase Values } \\
\hline Group & $\mathbf{n}$ & $\left(X^{-} \pm \mathrm{SD}\right)$ & $(\bar{X} \pm \mathrm{SD})$ & $\mathbf{z}$ \\
\hline Direct Teaching Model & 18 & $2.17 \pm 2.26$ & $37.67 \pm 8.52$ & $-3.73 * *$ \\
Tactical Game Approach & 25 & $2.96 \pm 5.93$ & $38.32 \pm 7.20$ & $-4.38^{* *}$ \\
\hline
\end{tabular}

$$
* * p<.001
$$

The success status of the groups was found with the total of the points for the cognitive field skills. The intra-group change for the general success status for both groups has been shown in Table 6. When both groups were assessed within themselves, it was determined that there was a statistically significant increase $(p<.001)$.

Table 7. Game Performance Indices and Change Percentages of the Groups

\begin{tabular}{|c|c|c|c|c|}
\hline & Criteria & & $\begin{array}{c}\text { Pre-test } \\
\text { Index }\end{array}$ & $\begin{array}{c}\text { Post-test } \\
\text { Index }\end{array}$ \\
\hline \multirow{6}{*}{ 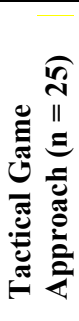 } & \multirow{2}{*}{ Decision-making } & Offense & 0.24 & 0.92 \\
\hline & & Defense & 0.13 & 0.73 \\
\hline & \multirow{2}{*}{ Support } & Offense & 0.35 & 1.00 \\
\hline & & Defense & 0.23 & 0.76 \\
\hline & \multirow{2}{*}{ Skills } & Offense & 0.26 & 0.62 \\
\hline & & Defense & 0.29 & 0.77 \\
\hline \multirow{6}{*}{ 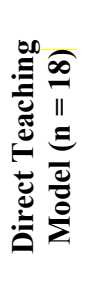 } & \multirow{2}{*}{ Decision-making } & Offense & 0.37 & 0.46 \\
\hline & & Defense & 0.25 & 0.33 \\
\hline & \multirow{2}{*}{ Support } & Offense & 0.31 & 0.48 \\
\hline & & Defense & 0.17 & 0.31 \\
\hline & \multirow{2}{*}{ Skills } & Offense & 0.30 & 0.35 \\
\hline & & Defense & 0.52 & 0.47 \\
\hline
\end{tabular}

$\Delta \%=$ Percentage change in means

In the data examined in Table 7, the game performance indices and the change in the performance levels for the tactical game approach and the direct learning model groups have been stated as percentages. 


\section{Discussion}

In this study, both quantitative and qualitative research methods were used by comparing the Tactical Game Approach and the Direct Learning Models in Handball training, which was realized with the objective of examining the effects of these models on the cognitive field, psychomotor field and game performance.

According to the first test and final test results of the study groups, which determined the development within themselves, statistically significant differences were found for all of the skills in the psychomotor field $(\mathrm{p}<.001)$. On this point, it was determined that both of the training methods made a contribution to the development in the psychomotor field. When the averages and the intra-group comparisons were examined for the percentage development differences of both groups within themselves, it was found that there were no statistically significant differences in the intra-group percentage development $(\mathrm{p}>.05)$. However, an interesting finding is that each study group showed high standart deviation regarding general success level for the psychomotor field. This could be due to inter individual differences in several characteristics such as personality, psycho-social skills and self- efficacy. Another possible reason could be different rates in adaptation level to learning styles (Jonassen \& Grabowski; 1993, Mosston \& Ashworth 2008; Tippin et al 2012).

In the findings for the cognitive field, which is another dimension of the study, it was determined that there was a statistically significant increase when the analyses made within the own groups of the students were examined ( $p$ $<.001)$. When the values between groups were compared, it was found that there was no statistically significant difference in the first and final test values for the cognitive field. In the study made by Chatzipanteli et al. (2016), as a result of the first test and final test assessments on the increase in the metacognitive behavior of students for the Tactical Game Approach in the volleyball branch of learning, they stated that the metacognitive behavior increased at the level of $22.53 \%$ with the Tactical Game Approach model. In the study made by Smith et al. (2015) to compare the Direct Learning Model and the Tactical Game Model for determining the physical activity levels and motivational reactions of females and males in physical education courses (6-12 weeks), they stated that from the aspect of motivation there was an insignificant difference for males and females in both groups and from the aspect of the level of physical activity, there was a significant difference between the first test - final test in females in the Tactical Game Group.

The Game Performance criteria of the working groups were assessed by percentage with the first and final test values. When the results obtained were examined, it drew attention that the development percentages of the participants in the tactical game approach group were rather high compared to the participants in the direct learning model group. In this context, it can be stated that in the handball game training, the tactical game approach model provided for a better game performance development compared to the direct learning model. Despite the fact that there is not a direct study that would support the findings of our study, our findings displayed similarities and differences to the study findings made by Alarcon et al. (2009), Roberts \& Fairclough (2011), Doydu et al. (2013), Miller et al (2015).

According to the findings obtained at the qualitative dimension of our study, the result was obtained that in both of the study groups, there was an average development in all fields at the ratio of $53-58 \%$ and in a positive direction. It was determined that the descriptive analysis results made showed a similarity to the quantitative results. The participants in both of the study groups stated that their levels of knowledge for the handball game were "almost nothing at all" $(\mathrm{n}=36)$, however, at the end of the 12-week training, they stated that they learned many concepts, rules and information regarding this branch $(\mathrm{n}=44)$. A portion of the responses given for the cognitive data have been given below:

"I had basic knowledge about some impressions... At the end of training, I learned the playing field measurements, drawing the playing field, game penalties, $7 \mathrm{~m}$ throw, all of the basic rules and moreover, I even learned that one cannot intervene within the goal area" (Ş, male, direct learning model group).

"I had close to zero knowledge... Now, when I watch or play a handball game, I am not unfamiliar with the game. I learned the rules of the game and all of the basic techniques" (R, male, tactical game approach group).

"I had no knowledge at all... If I go to a team at present, I will not grin stupidly): I am that knowledgeable"... (P, female, direct learning model group).

The qualitative data obtained with the interpretation of the psychomotor field developments, which are another dimension of the study, showed a parallelism to the quantitative data. The views of a number of participants for the psychomotor field have been given below:

"I could only hold the ball... I learned to receive and pass the ball, to make basic throws, to shoot, to give priority, to go forward and backward and to engage in team defense" (A, male, tactical game approach group). 
"My skills were almost nonexistent... I developed even more in the application field, I know what I should do when I take the ball in my hands" ( $\mathrm{T}$, male, tactical game approach group).

"I was inadequate... I am better able to take steps, make basic passes, dribble the ball and shoot the ball" (O, male, direct learning model group).

When the qualitative data was examined for the Game Performance Assessment, which is the final dimension in the study, a majority of the participants gave positive responses and especially the individuals included in the tactical game approach group drew attention with their statements that the course passed pleasurably and that their participation in the game increased and showed parallelism to the quantitative data.

"I was only holding the ball, I was saying let me get rid of it right away... Now, I can dribble the ball, think and implement my movements." ( $\mathrm{P}$, female, tactical game approach group).

"I was inadequate... I learned where I should run, where I should pass and where I should shoot. I can make a decision of what I should do where" (U.D., male, tactical game approach group).

"We were inadequate... We developed change of position, to enter inside suddenly and to defend. The competition increased and we were playing pleasurable games" (A, male, tactical game approach group).

"We were playing with improvisation.... We learned techniques and tactics. We started to play with flawless game rules" (V, male, direct learning model group).

"I was passive in the games.... I learned to be a part of the team, to take responsibility and to provide harmony. I developed on the subject of how a group game should be played" (Ş, female, direct learning model group).

\section{Conclusion}

In conclusion, the assessments for the study findings stated that both of the learning methods provided development, both in the psychomotor and in the cognitive field. However, in the game performance field, it was determined that the Tactical Game Approach was more effective compared to the Direct Learning Model. In the data obtained in light of the qualitative findings, it was observed that the developmental expressions in both groups were very close to each other. However, in the quantitative data, it was determined that in the decision-making, support and skills development dimensions, especially the tactical game approach group was more successful. It can be thought that this result sets forth that games unique to the handball branch of sports should be played more, that opportunities should be given to students in the solution of problems and that they should be encouraged to make decisions in the Tactical Game Approach model.

On this point, it can be thought that the Tactical Game Approach would be more productive in the target of learning the handball branch of sports in a short work period at the physical education departments of the universities. Especially, it can be stated that it would be meaningful for the candidates who will engage in physical education teaching to benefit from the Tactical Game Approach method for being able to attain more effective results in a shorter period of time in the process of branch learning. From another aspect, when it is taken into consideration that the period of time set aside for the handball branch of sports is 4-6 weeks in the curricula for Middle School and High School Physical Education in Turkey, it could be projected that the Tactical Game Approach would be more productive in the internalizing of the handball branch of sports by students.

\section{References}

Aelterman, N., Vansteenkistea, M., Keerb, V.H., Meyerc, D.J., Berghed, V.D.L., \& Haerensd, L. (2013). Development and evaluation of a training on need-supportive teaching in physical education: Qualitative and quantitative findings. Teaching and Teacher Education, 29, 64-75. https://doi.org/10.1016/j.tate.2012.09.001

Alarcon, F., Cardenas, D., Miranda, M.T., Urena, N., Pinar, I.M., \& Torre, E. (2009). Effect of a training program on the improvement of basketball players' decision making. Revista de Psicologia del Deporte, 18, 403-407.

Berg, L.B. (2004). Qualitative Research methods for social sciences. Pearson Education, fifth edition.

Bowering, M., Leggett, M.B., Harvey, M., \& Hui, L. (2007). Opening up thinking: reflections on group work in a bilingual postgraduate program. International Journal of Teaching and Learning in Higher Education, 19(2), 105-116. 
Chatzipanteli, A., Digelidis, N., Karatzoglidis, C., \& Dean, R. (2016). A tactical-game approach and enhancement of metacognitive behaviour in elementary school students. Physical Education and Sport Pedagogy, $21(2), 169$ -184, https://doi.org/10.1080/17408989.2014.931366.

Creswell, W.J. (2003). Research Design; Qualitative, Quantitative and Mixed Methods Approaches(2nd ed.). Sage publications, second edition, 22-26.

Curtner-Smith, D.M., Todorovich, R.J., McCaughtry, A.N., \& Lacon, A.S. (2001). Urban teachers's use of productive and reproductive teaching styles within the confines of the national curriculum for physical education. European Physical Education Review, 7(2), 177-190. https://doi.org/10.1177/1356336X010072005.

Doydu, İ., Çelen, A., \& Çoknaz, H. (2013). Spor eğitimi modeli’nin öğrencilerin beden eğitimi ve spora karş1 tutumuna etkisi [The effect of the sports education model on the attitudes of students towards physical education and sports]. International Journal of Educational Research, 4(2), 99-110.

Dyson, B., Griffin, L.L. \& Hastie, P. (2004). Sport education, tactical games, and cooperative learning: theoretical and pedagogical considerations. National Association for Kinesiology and Physical Education in Higher Education, 56, 226-240. https://doi.org/10.1080/00336297.2004.10491823

Gibbs, G., \& Coffey, M. (2004). The impact of training of university teachers on their teaching skills, their approach to teaching and the approach to learning of their students. Active Learning in Higher Education, 5(1), 87- 100. https://doi.org/10.1177/1469787404040463

Griffin, L.L., \& Butler, J.I. (2005). Teaching games for understanding, theory, research and practice. Human Kinetics, 149- 153.

Griffin, L.L., Mitchell, S., \& Oslin, J. (1997). Teaching sport concepts and skills: a tactical games approach. Champaign, IL: Human Kinetics.

Gürbüz, S., \& Şahin, F. (2014). Sosyal bilimlerde araştırma yöntemleri felsefe - yöntem - analiz [Research methods in social sciences; philosophy - methodology - analysis]. Seçkin Yayınc1lık, 103-108.

İnce, L. \& Hünük, D. (2007). Eğitim reformu sürecinde deneyimli beden eğitimi öğretmenlerinin kullandıkları öğretim stilleri ve stillere ilişkin algıları. [Experienced physical education teachers's use and perceptions of teaching styles during the educational reform period]. Eğitim ve Bilim, 35(157), 129-138.

Jenkinson, K., \& Benson, A. (2009). Physical education, sport education and physical activity policies: Teacher knowledge and implementation in their Victorian state secondary school. European Physical Education Review, 15(3), 365-388. https://doi.org/10.1177/1356336X09364456.

Jonassen H.D., \& Grabowski L.B. (1993). Handbook of individual differences, learning and instruction. Lawrence Erlbaum Associates, Hillsdale, NJ, 233-300.

Lloyd, J.R. (2012). Moving to learn and learning to move: A phenomenological exploration of children's climbing with an interdisciplinary movement consciousness. The Humanistic Psychologist, 40, 23-37. https://doi.org/10.1080/08873267.2012.643683

McNeill, C.M., \& Fry, M.J. (2010). Motivational climate in games concept lessons. Journal of Research National Institute of Education, 6(1), 34-38.

Memmert, D., \& Harvey, S. (2008). The game performance assessment instrument (GPAI): Some concerns and solutions for further development. Journal of Teaching in Physical Education, 27, 220-240. https://doi.org/10.1123/jtpe.27.2.220

Metzler, M.W. (2005). Instructional models for physical education (2nd Ed.). United States of America: Holcomb Hathaway, Inc.

Miller, A., Christensen, E., Eather, N., Gray, S., Sproule, J., Keay, J., \& Lubans, D. (2015). Can physical education and physical activity outcomes be developed simultaneously using a game-centered approach? European Physical Education Review, 22, 1-21. https://doi.org/10.1177/1356336X15594548.

Mitchell, S.A., Oslin, J.L., \& Griffin, L.L. (2003). Sport foundations for elementary physical education: A tactical games approach. Champaign, IL: Human Kinetics.

Mosston, M., \& Ashworth, S. (2008). Teaching Physical Education. Pearson Education- First Online Edition, 188-209. 
Oslin, JL., Mitchell, S.A., \& Griffin, L.L. (1998). The game performance assessment instrument (GPAI): development and preliminary validation. Journal of Teaching in Physical Education, 17, 231-243. https://doi.org/10.1123/jtpe.17.2.231

Pritchard, T., Hawkins, A., Wiegand, R., \& Metzler, N.J. (2008). Effects of two instructional approaches on skill development, knowledge and game performance. Measurement in Physical Education and Exercise Science, 12(4), 219-236. https://doi.org/10.1080/10913670802349774

Roberts, S., \& Fairclough, S. (2011). Observational analysis of student activity modes, lesson contexts and teacher interactions during games classes in high school (11-16 years) physical education. European Physical Education Review, 17(2), 255-268. https://doi.org/10.1177/1356336X11420222.

SHAPE America (2015). Society of health and physical educators: The Essential Components of Physical Education, 2.

Smith, L., Harvey, S., Savory, L., Kozub, S., \& Kerr, C. (2015). Physical activity levels and motivational responses of boys and girls: A comparison of direct instruction and tactical games models of games teaching in physical education. European Physical Education Review, 21(1), 93-113. https://doi.org/10.1177/1356336X14555293.

Stolz, S., \& Pill, S. (2014). Teaching games and sport for understanding: Exploring and reconsidering its relevance in physical education. European Physical Education Review, 20(1), 36-71. https://doi.org/10.1177/1356336X13496001.

Stran, M. \& Curtner-Smith, M. (2009). Influence of occupational socialization on two preservice teachers'. Interpretation and delivery of the sport education model. Journal of Teaching in Physical Education, 28, 38-53. https://doi.org/10.1123/jtpe.28.1.38

Tippin, K.G., Kathryn, D., Lafreniere, D.K., \& Page, S. (2012). Student perception of academic grading: Personality, academic orientation, and effort. Active Learning in Higher Education, 13(1), 51-61. https://doi.org/10.1177/1469787411429187

Tozer, S., \& Horsley, H. (2006). Professional development of teachers in physical education- where are we now? Journal of Teaching in Physical Education, 25, 450-457. https://doi.org/10.1123/jtpe.25.4.450

Wallhead, L.T., \& Nikos Ntoumanis, N. (2004). Effects of a sport education intervention on students' motivational responses in physical education. Journal of Teaching in Physical Education, 23(1), 4-18. https://doi.org/10.1123/jtpe.23.1.4

Yıldırım, A., \& Şimşek, H. (2008). Sosyal bilimlerde nitel araştırma yöntemleri [Qualitative Research methods for social sciences, 6th ed.]. Baskı, Seçkin Publishing.

Zembat, Ö.İ. (2007). "Yansıma dönüşümü, doğrudan öğretim ve yapılandırmacılığın temel bileşenleri” [The main tenets of direct instruction and constructivism: the case of translation]. Gazi Eğitim Fakültesi Dergisi, 27(1), 195-213. 